\title{
Physiological quality and imbibitions of soybean seeds with contrasting coats ${ }^{1}$
}

\author{
Qualidade fisiológica e embebição de sementes de soja com tegumentos contrastantes
}

\author{
Carlos André Bahry ${ }^{2 *}$, Anelise Tessari Perboni ${ }^{3}$, Maicon Nardino ${ }^{4}$ and Paulo Dejalma Zimmer ${ }^{4}$
}

\begin{abstract}
The attributes that confer seed quality can largely be considered dependent on the coat. The aim of this study was to evaluate the quality and hydration pattern of the seeds of four contrasting soybean genotypes for the coats characteristics; BMX Potência RR and CD 202 with yellow coats and IAC and TP with black coats. The first stage of the study consisted of seed multiplication in the 2012/2013 harvest. After storage for five months at a temperature of $17{ }^{\circ} \mathrm{C}$ and a relative humidity of $50 \%$, the seeds were subjected to the following tests: germination, first count and seedling height, with and without immersion of the seeds, emergence in soil, emergence speed and germination index; electrical conductivity; thousand weight seeds and imbibitions of seeds. The design was completely randomized, with five replicates. The data was subjected to variance analysis and the means compared using the Tukey test at a 5\% level of probability. Regression analysis was used for the seeds imbibitions test. Genotypes with black coats (especially IAC) presented better physiological quality in relation to genotypes with yellow coats. The latter had greater thousand weight seeds. BMX Potência RR presented greater hydration than the other genotypes in the first hours of imbibitions and TP, the least. Genotypes with black coats emitted a radicle faster than the yellow coats genotypes.
\end{abstract}

Key words: Seed performance. Glycine max. Hydration. Thousand weight seeds.

\begin{abstract}
RESUMO - Os atributos que conferem a qualidade das sementes podem ser considerados, em grande parte, dependentes do tegumento. O objetivo do trabalho foi avaliar a qualidade e o padrão de hidratação das sementes de quatro genótipos de soja contrastantes para as características de tegumento; BMX Potência RR e CD 202, de tegumentos amarelos e, IAC e TP, de tegumentos pretos. A primeira etapa do estudo constou da multiplicação das sementes, na safra 2012/2013. Depois de cinco meses armazenadas à temperatura de $17{ }^{\circ} \mathrm{C}$ e $50 \%$ de umidade relativa do ar, as sementes foram submetidas aos testes de germinação, primeira contagem e comprimento de plântula, com e sem imersão das sementes; emergência em solo; índice de velocidade de emergência e germinação; condutividade elétrica; massa de mil sementes e embebição das sementes. O delineamento foi o inteiramente casualizado, com cinco repetições. Os dados foram submetidos à análise de variância e as médias comparadas pelo teste de Tukey, ao nível de 5\% de probabilidade. Para o teste de embebição das sementes aplicou-se análise de regressão. Genótipos de tegumento preto (em especial o IAC) apresentam maior qualidade fisiológica em relação aos de tegumento amarelo. Estes últimos possuem maior massa de mil sementes. BMX Potência RR apresenta hidratação maior que os outros genótipos nas primeiras horas de embebição e TP, a menor. Genótipos de tegumento preto emitem a radícula mais rápido que genótipos de tegumento amarelo.
\end{abstract}

Palavras-chave: Desempenho de sementes. Glycine max. Hidratação. Massa de mil sementes.

DOI: $10.5935 / 1806-6690.20170014$

*Autor para correspondência

${ }^{1}$ Recebido para publicação em 21/02/2014; aprovado em 12/04/2016

Trabalho extraído da Tese de Doutorado do primeiro autor apresentada à Universidade Federal de Pelotas/UFPel

${ }^{2}$ Departamento de Agronomia, Universidade Tecnológica Federal do Paraná, câmpus Dois Vizinhos, Dois Vizinhos, Paraná-PR, Brasil, carlosbahry@utfpr.edu.br

${ }^{3}$ Departamento de Engenharia de Bioprocessos e Biotecnologia, Universidade Tecnológica Federal do Paraná, câmpus Dois Vizinhos, Dois Vizinhos, Paraná-PR, Brasil, aneliseperboni@utfpr.edu.br

${ }^{4}$ Departamento de Agronomia, Área de concentração em Fitomelhoramento, Universidade Federal de Pelotas, Pelotas, Rio Grande do Sul-RS, Brasil, maiconmn@gmail.com,dejalma@msn.com 


\section{INTRODUCTION}

The soybean coat is the modulator of the interactions between the internal structures of the seed and the external environment. It acts in the preservation of seed integrity, protecting the embryo and reserve tissues against pest attacks, disease, mechanical damage, deterioration and, as well, modulates the gas exchange with the environment and water absorption, especially during the germination process (SOUZA; MARCOSFILHO, 2001).

Furthermore, the coats exercise a special function in regard to the supply of nutrients to the embryo during seed development (MOÏSE et al., 2005; WEBER; BORISJUK; WOBUS, 2005).

Despite the progress made over the years in the area of seed science and technology, the study by Carraro and Peske (2005) showed that the physiological quality of soybean seeds from certain regions had been compromised by elevated levels of deterioration due to humidity and the rupture of the coat associated with mechanical damage at harvest and during postharvest. This situation is due to the fragility of the coat of the cultivars currently available for agricultural use. However, this characteristic is variable between the different genotypes (FLOR et al., 2004).

Work carried out to improve the quality of soybean seeds has found some responses in the coat that can contribute to minimizing the problems related to this issue (MA et al., 2004; MENEZES et al., 2009; MERTZ et al., 2009; RANATHUNGE et al., 2010; SANTOS et al., 2007; SHAO et al., 2007).

Some researchers have found that black colored coats present a semi-impermeability to water, which confers greater resistance to deterioration in the field after physiological maturity; slower soaking during the germination process, allowing better reorganization of the membrane system; and, less mechanical damage in comparison to yellow and permeable coats which are characteristics of the cultivar traditionally cultivated (MERTZ et al., 2009; SANTOS et al., 2007).

However, despite the knowledge of the properties of black colored coats, such as semi-permeability, greater epidermal thickness, higher concentrations of phenolic compounds and lignin, which confer on them superior characteristics in relation to the genotypes with yellow coat (ANDRADE, 2012; BAHRY et al., 2015; MERTZ et al., 2009; SANTOS et al., 2007). Research aimed at elucidating other attributes of this type of seed is not adequately explored. As an example, the limited information generated in respect to the physiological characteristics of these contrasting seeds as well as their hydration patterns can be mentioned.
Based on the above, the present study aimed to evaluate the physiological quality and hydration pattern of the seeds of four contrasting genotypes for the coat characteristics; two with yellow coats and two with black coats.

\section{MATERIAL AND METHODS}

The first stage of the experiment was conducted in sites in Santo Augusto city, in Rio Grande Do Sul state, where the seeds were propagated in the 2012/2013 harvest. The soil at the test site is classified as Purple Distroferric Latosol and the climate as Cfa under the Köppen-Geiger climate classification system.

The average temperature during the test period was $21.3{ }^{\circ} \mathrm{C}$ and precipitation around $870 \mathrm{~mm}$ (INMET, 2013).

Four contrasting soybean genotypes were used based on the characteristics of their coat - the CD 202 (conventional) and BMX Potência RR (genetically modified -RR®) cultivars, both with yellow seed coat and the TP and IAC genotypes, both with black seed cota.

Each plot consisted of six rows with spacing of 0.45 meters and 3 meters in length. Weed control was performed manually. An application the pyrethroid insecticide lambda cyhalothrin in the $\mathrm{R}_{2}$ state was used for the control of Diabrotica speciosa, at a dose of $150 \mathrm{ml} \mathrm{ha}^{-1}$ of the commercial product. The systemic fungicide Azoxystrobin Cyproconazole was applied as a preventative measure in two applications of $300 \mathrm{ml} \mathrm{ha}^{-1}$, in the $\mathrm{R}_{1}$ and $\mathrm{R}_{5}$ states (FEHR; CAVINESS, 1977).

The external rows of each plot were eliminated at the time of harvest and 0.5 meters of the border of each remaining row. The legumes were harvested manually and the seeds collected in the same manner to preserve their integrity. The moisture content of the seeds was determined using the kiln method at $105^{\circ} \mathrm{C}$ for 24 hours (BRAZIL, 2009), being around $12.6 \%$. Soon thereafter, they proceeded to storage in a cold and dry room (temperature of $15^{\circ} \mathrm{C}$ and $50 \%$ relative humidity) where they remained for a period of five months wrapped in permeable paper packaging.

The second phase consisted of the evaluation of the quality of seeds, by performing the following tests:

Germination test: performed according to the Rules for Seed Analysis (BRASIL, 2009).

First count: performed concomitantly with the germination test, counting the normal seedling at five days from the start of the test. 
Seedling height: determined from the normal seedlings arising from the germination first count, taking a reading of the shoot height, the root length and the total height of each seedling.

Germination test and first count of seeds subjected to immersion in water: Fifty seeds of each genotype were placed in plastic cups containing $75 \mathrm{ml}$ of deionized water and kept at $20{ }^{\circ} \mathrm{C}$ for 24 hours. After this, they then proceeded to the standard germination test and the first count.

Seedling height with seed immersion: Prior immersion of seeds in water for 24 hours and conduction and evaluation according to seedling height without immersion.

Emergence in soil: Fifty seeds of each genotype were sown in $500 \mathrm{ml}$ plastic cups, putting 5 seeds per cup at a depth of three centimeters. The emerged seedling count commenced at 14 days from sowing.

Emergence speed index: Performed in conjunction with the emergence in soil test. The count of the emerged seedlings was performed daily until emergence was established. The emergence speed index (ESI) was calculated based on the seedlings emerged at each reading, (MAGUIRE, 1962), correcting the value for $100 \%$ emergence.

Germination speed index: Fifty seeds of each genotype were sown in gerbox type boxes with a blotting paper substrate moistened with 2.5 times its mass with distilled water. The seeds remained at $25{ }^{\circ} \mathrm{C}$ during the entire evaluation period. The readings were taken daily until germination was established, the calculations made in accordance with Maguire (1962), correcting the value for $100 \%$ germination.

Electricalconductivity: The electrical conductivity test was used by the mass of seeds. Therefore, fifty intact seeds of each genotype were weighed using $0.0001 \mathrm{~g}$ precision scales, placed in plastic cups containing $75 \mathrm{ml}$ of deionized water and kept at $20{ }^{\circ} \mathrm{C}$ for 24 hours. The electrical conductivity of the solution was subsequently measured using a Digimed CD-20 conductivity meter and the data obtained, expressed in $\mu \mathrm{S} \mathrm{cm}^{-1} \mathrm{~g}^{-1}$ of seeds.

Thousand weight seeds: The thousand weight seeds was determined for each genotype from a random count of one thousand seeds, divided into five repetitions of two hundred seeds.

Imbibitions of Seeds: Water gain was determined in four genotypes, with all the seeds of a standardized size, retained in a sieve with 5.5-6.0 $\mathrm{mm}$ round perforations. Fifty seeds were used, distributed in $200 \mathrm{ml}$ plastic cups with the addition of $65 \mathrm{ml}$ of distilled water in each. The seed mass was determined using precision scales $(0.0001 \mathrm{~g})$, with readings taken every 30 minutes in the first 12 hours; every hour from 12 to 28 hours; every two hours from 28 to 36 hours; and every three hours from 36 to 42 hours.

The experimental design was completely randomized with five repetitions. The data obtained in the laboratory was subjected to variance analysis and the means compared using the Tukey test at a level of $5 \%$ probability. Regression analysis was used for the imbibitions seeds test.

\section{RESULTS AND DISCUSSION}

The data relating to the variance analysis is presented in Tables 1a, 1b and 1c.

The results of the germination test of contrasting seed for the coat characteristic did not present significance (Table 1a), with an elevated percentage of germination for all genotypes, with a minimum of $98 \%$ (Table 2).

This high percentage of germination observed for the four soybean genotypes can be related to the way the seeds were harvested, that is manually, as well as the way it was threshed, to avoid mechanical damage in the seeds. These results are in accordance with those observed by

Table 1a - Summary of the variance analysis of variables analyzed in the seeds of four contrasting soybean genotypes for coat characteristics

\begin{tabular}{lccccccccc}
\hline \multirow{2}{*}{ SV } & \multirow{2}{*}{ DF } & \multicolumn{1}{c}{ Mean Square } \\
\cline { 2 - 10 } & & TKW & G & FC & SH & RL & TH & G $^{\mathbf{1}}$ & FC $^{\text {1 }}$ \\
\hline Gen. & 3 & $47.47^{*}$ & $16.0^{\text {ns }}$ & $6.4^{\text {ns }}$ & $6.22^{*}$ & $0.12^{\text {ns }}$ & $6.91^{*}$ & $75.47^{*}$ & $1797.33^{*}$ \\
Residue & 16 & 0.02 & 51.2 & 7.6 & 0.48 & 0.43 & 1.35 & 16.80 & 106.80 \\
CV $(\%)$ & & 1.38 & 1.81 & 2.82 & 7.68 & 5.13 & 5.33 & 4.45 & 13.53 \\
\hline
\end{tabular}

SV - Source of variation; Gen. - Genotypes; DF - Degree of Freedom; ns - no significance; *significant to $1 \%$ probability; TKW - Thousand weight seeds; G - germination; FC - first count; SH - shoot height; RL - Root length; TH - Total seedling height; G $^{\mathbf{1}}$; FC ${ }^{\mathbf{1}}$ - same meaning as previous acronyms, however, with prior seed immersion in water for 24 hours 
Table 1b - Summary of the variance analysis of variables analyzed in the seeds of four contrasting soybean genotypes for coat characteristics

\begin{tabular}{lcccccccc}
\hline \multirow{2}{*}{ SV } & \multirow{2}{*}{ DF } & \multicolumn{9}{c}{ Mean Square } \\
\cline { 2 - 8 } & & SH $^{1}$ & RL $^{1}$ & TH $^{1}$ & E & ESI & GSI & EC \\
\hline Gen. & 3 & $14.31^{*}$ & $17.79^{*}$ & $50.96^{*}$ & $66.67^{\text {ns }}$ & $12.34^{*}$ & $24.82^{*}$ & $4.39^{\text {ns }}$ \\
Residue & 16 & 0.19 & 0.46 & 0.82 & 42.50 & 0.33 & 0.21 & 3.40 \\
CV $(\%)$ & & 6.36 & 6.65 & 5.35 & 6.79 & 7.56 & 4.39 & 2.76 \\
\hline
\end{tabular}

SV - Source of variation; Gen. - Genotypes; DF - Degree of Freedom; ns - no significance; *significance of 1\% probability; SH $^{1}$ - shoot height; $\mathrm{RL}^{1}$ - root length; $\mathrm{TH}^{1}$ - total seedling height. ${ }^{1}$ with prior immersion of seeds in deionized water; $\mathrm{E}$ - emergence in soil; ESI - emergence speed index; GSI - germination speed index; EC - electric conductivity

Table 1c - Summary of the analysis of variance relating to the interaction between contrasting soybean genotypes for coat characteristics and seed soaking time

\begin{tabular}{|c|c|c|}
\hline SV & $\mathrm{DF}$ & Square Mean Seed soaking \\
\hline Genotype & 3 & $7991.41^{*}$ \\
\hline Time & 46 & $26956.17 *$ \\
\hline Genotype $\mathrm{x}$ Time & 138 & $177.71 *$ \\
\hline Repetition & 4 & $561.61 *$ \\
\hline $\mathrm{R}^{2}$ & 0.99 & \\
\hline $\mathrm{CV}(\%)$ & 4.8 & \\
\hline
\end{tabular}

$\mathrm{SV}$ - Source of variation; Time: Seed soaking time; DF - Degreee of freedom; *significance of $1 \%$ probability

Mertz et al. (2009), which also found no difference in the germination test for the black TP cultivar and the CD202 cultivar with yellow coat.

The verified results differed to those observed by Santos et al. (2007). According to the authors, of the three cultivars tested, with coloration of coats varying from yellow to brown, it was observed that one of these, with the brown coloration, presented a higher germination percentage. The same result, however, was not confirmed for the other cultivars with different coloration. However, in absolute terms, the average germination percentage was superior in brown colored seeds, and these authors stated that this result was probably due to a greater quantity of lignin in the coat, which as well, probably conferred better quality to the seeds.

By analyzing the chemical composition of the coat of the four genotypes used in this study, Bahry et al. (2015) demonstrated that the genotypes with black coat, IAC and TP, showed higher lignin values than the CD 202 and BMX Potência RR cultivars. It appears, however, that that the greater quantity of lignin does not interfere in seed germination (Table 2).

A similar pattern to germination was found in the first count, demonstrating that both tests were not sensitive enough to distinguish the contrasting genotypes by the coat characteristic for its physiological qualities.

In relation to seedling height, a higher value was observed in the shoot height in the IAC genotype with black coat compared to the other varieties. That was an exception in the total seedling height variable in which the respective genotypes did not differ. TP, as well with a black coat and the CD 202 and BMX Potência RR cultivars, both with yellow coat, did not differ for the variable in question.

By characterizing the physiological qualities of the different soybean genotypes, Andrade (2012), by means of the seedling shoot height, confirmed that the highest values were observed in the TMG 801 cultivar with yellow coat and the UnB 1125 genotype with black coat; a result similar to that found for TP and the cultivars with yellow coat.

These first analyses indicate that there is no difference between the genotypes in their seed quality in function of their color, but only related to the particular genotype.

There was no significance for root length between the genotypes (Table 2). According to Vanzolini et al, 
Table 2 - Mean germination data (G), germination first count (FC), shoot height (SH), root length (RL), total seedling height (TH), of the black coat soybean genotypes IAC and TP and CD 202 and BMX Potência RR, the soybean cultivars with yellow coat

\begin{tabular}{lccccc}
\hline \multirow{2}{*}{ Genotypes } & \multicolumn{5}{c}{ Variables } \\
\cline { 2 - 6 } & $\mathrm{G}(\%)$ & $\mathrm{FC}(\%)$ & $\mathrm{SH}(\mathrm{cm})$ & $\mathrm{RL}(\mathrm{cm})$ & $\mathrm{TH}(\mathrm{cm})$ \\
\hline IAC & $98^{2}$ & $98^{2}$ & $10.58 \mathrm{a}^{1}$ & $12.89^{2}$ & $23.47 \mathrm{a}^{1}$ \\
TP & 98 & 97 & $8.95 \mathrm{~b}$ & 12.92 & $21.87 \mathrm{ab}$ \\
CD 202 & 99 & 97 & $7.97 \mathrm{~b}$ & 12.85 & $20.82 \mathrm{~b}$ \\
BMX Potência & 100 & 99 & $8.57 \mathrm{~b}$ & 12.58 & $21.15 \mathrm{~b}$ \\
CV $(\%)$ & 1.81 & 2.82 & 7.68 & 5.13 & 5.33 \\
\hline
\end{tabular}

${ }^{1}$ Means followed by lowercase letters in the column differ by the Tukey test, at a level of $5 \%$ probability. ${ }^{2}$ no significance

(2007), the root length of the soybean seedlings is one of the most sensitive parameters to separate lots with distinct levels of vigor, with this test directly related to emergence in soil. This finding is in line with the results observed in this study as there was no significant difference between the genotypes in emergence in soil (Table 4).

The same variable from Table 2 was reanalyzed, however, subjecting the seeds to prior immersion in deionized water for 24 hours at a temperature of $20{ }^{\circ} \mathrm{C}$. The procedure aimed to shock the seeds to verify their behavior pattern.

According to the results presented in table 3, when immersed in water, the genotypes presented differences in the germination percentages. The seeds of the IAC genotype, with black coat, were more tolerant to immersion compared to the CD 202 genotype, presenting a higher percentage of normal seedlings at the end of the germination test. However, IAC did not differ from TP and BMX Potência RR, which as well did not differ from CD 202. This result is in line with the findings of Gray et al. (2010). According to the authors, immersion of the seeds immediately prior to the germination test provokes a reduction in this parameter in genotypes with more sensitive coats, reducing the number of normal seedlings.

The observed results probably occurred due to the greater water permeability of the coat of the CD 202 cultivar. This genotype is considered more susceptible to deterioration as a result of moisture and mechanical damage, precisely because of the lower resistance of its coat due to a lower concentration of lignin (BAHRY et al., 2015; MERTZ et al., 2009). This as well may lead to less control over the entry of water in the initial stage of seed soaking, not allowing an adequate reorganization of the membrane system, causing irreversible damage to the embryo and, consequentially, reducing the number of normal seedlings (ZIMMER, 2012).
In relation to the germination first count (Table 3), vigor accompanied germination for the IAC and TP genotypes. As for the cultivars with yellow coat, CD 202 and BMX Potência RR, these as well did not differ between themselves, as CD 202 and TP did not after immersion of the seeds (Table 3 ).

It is salient to note that the first count of standard germination presented elevated values, close to seed germination (Table 2). However, when the seeds were immersed, the first count presented inferior results for all genotypes, primarily for the cultivars with yellow coat, namely BMX Potência RR with a lower percentage of normal seedlings (Table 3 ). This contact with water by means of immersion probably caused more rapid soaking in comparison with the use of moistened germitest paper. Consequently, the damage to the membrane system may have been greater; thus contributing to the results.

The height of the seedlings differed between the genotypes. In relation to the shoot, IAC was superior to TP and presented higher values than the cultivars with yellow coat. The result differed to that observed for root length in which no difference was observed in the length between the genotypes with yellow coat just as there was no difference between TP and CD 202 (Table 3).

Despite no difference having been verified in root length for some genotypes, it became evident, based on shoot height, that there was a distinction between the contrasting genotypes for the coat characteristics. In this case, IAC presented a larger seedling in relation to the others with the cultivars with yellow coat again being inferior to the genotypes with black coats (Table 3 ). According to studies undertaken by some authors, genotypes with black coats present a greater resistance to the entry of water, which is beneficial in the reorganization of cell membranes, thus contributing to greater vigor in the seeds. This semi-permeability is related to the greater amount of lignin in those with black coats than those with yellow, thus these seeds suffer less deterioration and 
Table 3 - Mean germination data $\left(\mathrm{G}^{1}\right)$, germination first count $\left(\mathrm{FC}^{1}\right)$, Shoot height $\left(\mathrm{SH}^{1}\right)$, root length $\left(\mathrm{RL}^{1}\right)$ and total seedling height $\left(\mathrm{TH}^{1}\right)$, obtained from seeds immersed in water for 24 hours ${ }^{1}$ ) from the soybean genotypes IAC and TP with black coat, and the soybean cultivars CD 202 and BMX Potência RR with yellow coat

\begin{tabular}{lccccc}
\hline \multirow{2}{*}{ Genotypes } & \multicolumn{5}{c}{ Varibles } \\
\cline { 2 - 6 } & $\mathrm{G}^{1}(\%)$ & $\mathrm{FC}^{1}(\%)$ & $\mathrm{SH}^{1}(\mathrm{~cm})$ & $\mathrm{RL}^{1}(\mathrm{~cm})$ & $\mathrm{TH}^{1}(\mathrm{~cm})$ \\
\hline IAC & $96 \mathrm{a}^{1}$ & $96 \mathrm{a}^{1}$ & $9.04 \mathrm{a}^{1}$ & $11.85 \mathrm{a}^{1}$ & $20.49 \mathrm{a}^{1}$ \\
$\mathrm{TP}$ & $94 \mathrm{ab}$ & $87 \mathrm{ab}$ & $7.37 \mathrm{~b}$ & $11.01 \mathrm{ab}$ & $18.37 \mathrm{~b}$ \\
$\mathrm{CD} 202$ & $87 \mathrm{~b}$ & $69 \mathrm{bc}$ & $5.39 \mathrm{c}$ & $10.26 \mathrm{~b}$ & $15.66 \mathrm{c}$ \\
BMX Potência & $91 \mathrm{ab}$ & $54 \mathrm{c}$ & $5.66 \mathrm{c}$ & $7.49 \mathrm{c}$ & $13.16 \mathrm{~d}$ \\
$\mathrm{CV}(\%)$ & 4.45 & 13.53 & 6.36 & 6.65 & 5.35 \\
\hline
\end{tabular}

${ }^{1}$ Means followed by lowercase letters in the column differ by the Tukey test, at a level of $5 \%$ probability

mechanical damage in the field (BAHRY et al., 2015; MERTZ et al., 2009; SANTOS et al., 2007).

The emergence of seedlings in soil presented behavior similar to the germination standard test; that is, there was no significant difference between the genotypes and, in absolute values, the percentage of emergence was greatly elevated (Table 4 ).

The emergence speed index (ESI), as opposed to the emergence of seedlings, presented differences between the genotypes with higher values being confirmed for IAC, followed by TP and BMX Potência RR; the latter two not differing between themselves. The lowest value for this variable was found in the CD 202 cultivar. This result indicates that IAC presented a faster initial establishment, and, consequentially, greater vigor in relation to the other genotypes (Table 4).

According to Peske and Pereira (1983), Santos et al. (2007) e Tavares et al. (1987), genotypes with a black coat absorb water at a slower rate which allows the membrane system to better reorganize and, with this, reduce stress in the germination process caused during water absorption allowing more rapid emergence. This slower absorption is related to lignin.

The genotypes with black coats do indeed present a greater concentration of lignin. The similarity of the speed of emergence in TP and BMX Potência RR is due to this genotype presenting an intermediary quantity of lignin between IAC (highest value) and CD 202 (lowest value) (BAHRY et al., 2015).

According to Gris et al. a hypothesis has been proposed in which soybeans genetically modified to have a greater resistance to the herbicide Glyphosate, have presented higher lignin values in the plant compared to conventional cultivars. This is based on the fact that the alterations were performed in a shikimic acid cycle, the same used by the plant to synthesize lignin. However, the research in this area is very limited between conventional cultivars and their respective RR versions.

The germination speed index followed the trend of the ESI results observed, showing the IAC genotype

Table 4 - Mean emergence data (E); emergence speed index (ESI); germination speed index (GSI); electrical conductivity (EC); and thousand kernel weight (TKW) of IAC and TP soybean genotypes with black integument, and CD 202 and BMX Potência RR, the cultivars with yellow integument

\begin{tabular}{lccccc}
\hline \multirow{2}{*}{ Genotypes } & \multicolumn{5}{c}{ Variables } \\
\cline { 2 - 6 } & $\mathrm{E}(\%)$ & ESI & GSI & $\mathrm{EC}\left(\mu \mathrm{S} . \mathrm{cm}^{-1} \cdot \mathrm{g}^{-1}\right)$ & $\mathrm{TKW}(\mathrm{g})$ \\
\hline IAC & $98^{2}$ & $1.52 \mathrm{a}^{1}$ & $13.80 \mathrm{a}^{1}$ & $67.09^{2}$ & $67.65 \mathrm{~d}^{1}$ \\
TP & 92 & $1.41 \mathrm{~b}$ & $9.28 \mathrm{~b}$ & 66.62 & $105.55 \mathrm{c}$ \\
CD 202 & 100 & $1.32 \mathrm{c}$ & $9.73 \mathrm{~b}$ & 65.60 & $149.23 \mathrm{a}$ \\
BMX Potência & 94 & $1.38 \mathrm{~b}$ & $9.90 \mathrm{~b}$ & 67.83 & $124.90 \mathrm{~b}$ \\
CV $(\%)$ & 6.79 & 7.56 & 4.66 & 2.76 & 1.38 \\
\hline
\end{tabular}

${ }^{1}$ Means followed by lowercase letters in the column differ by the Tukey test, at a level of $5 \%$ probability. ${ }^{2}$ no significance 
has more vigor in relation to the other varieties. In this test, the CD 202 soybean cultivar did not differ from TP and BMX Potência RR. Even though the GSI is a test which evaluates the speed of germination, it is conducted in conditions similar to the standard germination test in relation to substrate, humidity, luminosity and temperature (BRAZIL, 2009), which may have contributed to the minimization of the effects confirmed in the ESI (Table 4 ), in which the conditions are not so controlled.

Studying the soybean UnB 1125 genotype with black coat in relation to some commercial cultivars with yellow coat, Andrade (2012) found a lower germination speed index for the genotype, at the detriment of the cultivar, confirming that observed by Menezes et al. (2009), studying soybean as well. However, the author did not mention if the GSI had been corrected for $100 \%$ germination, which could affect the results found.

The electrical conductivity test is based on the relationship that exists between the vigor of the seeds and the integrity of the cell membranes, considering that greater vigor in the seeds leaches less into the solution over a given period of time (TILLMANN; MENEZES, 2012). In this study, the electrical conductivity was not sufficiently sensitive to stratify seeds by soybean genotype and no significance was found.

A study undertaken by Andrade (2012), showed greater sensitivity to differentiate the different levels of vigor in different cultivars in the first four hours in the electrical conductivity test, with the UnB 1125 soybean, a genotype with black coat, presenting the least leaching. Even with twelve hours soaking, this pattern remained, with closer values between the soybean genotypes and cultivars tested. This result is in line with the findings of Mertz et al. (2009), which found that soybean genotypes with black coat presented less leaching than CD 202, a soybean cultivar with yellow coat.

The mean data for the thousand kernel test revealed a distinct pattern amongst the soybean genotypes, with the CD 202 cultivar presenting greater seed mass, followed by BMX Potência RR (Table 4). This tendency was expected, since, in function of genetic improvement, the cultivars with yellow coat contain agronomic characteristics of interest, in this case, greater seed mass which is reflected in the crop productivity together with the number of seeds, the other primary yield component.

The genotypes with black integument presented the lowest seed mass, as demonstrated with IAC, with lower values observed amongst the others (Table 4). This lower value confirmed in the IAC soybean genotype can be related to the size of the seed which present greater retention in a 4.5-5 $\mathrm{mm}$ sieve. The rest of the genotypes presented a greater quantity of seeds retained in a 5.5-6 mm sieve.
However, this physical characteristic, according to Peske and Baudet Labbé (2012), did not influence the physical quality of the seeds as the difference in seed size was close to one millimeter as confirmed in this study.

By analyzing the soaking of the seeds of the different soybean genotypes, it was confirmed that the BMX Potência RR cultivar presented greater water gains in relation to the seeds of the other genotypes for up to approximately six hours, stabilizing thereafter.

The IAC genotype follows BMX Potência RR in the sequence for up to approximately four hours of soaking. After this period, the CD 202 cultivar presents greater gains in less time than the genotypes with black coats, stabilizing at 24 hours of hydration. TP was the genotype which absorbed the least water and did so more slowly for virtually the entire evaluation time of the soaking test. After 24 hours soaking, the water gains were almost stabilized, similar to that observed for CD 202 and IAC. This distinct water absorption pattern amongst the cultivars corroborates the results obtained by Braccini et al. (1997).

Genotypes with black coat absorb water more slowly (MERTZ et al., 2009; SANTOS et al., 2007), which allows them to better reorganize their membrane systems and, thus, reduce stress caused during water absorption for the germination process, allowing a more uniform stand in the crop and more rapid emergence. Nevertheless, based on the emergence and germination speed results (Table 4) and in accordance with that seen in Figure 1, it became clear that coloration did not influence the soaking rate, since IAC and PT presented initial water gains similar to the CD 202 cultivar. The BMX Potência RR cultivar was an exception.

Figure 1 - Water gains in the genotypes with black integument, IAC and TP, and the soybean cultivars with yellow integument, CD 202 and BMX Potência, in function of soaking time Soybean seed hydration

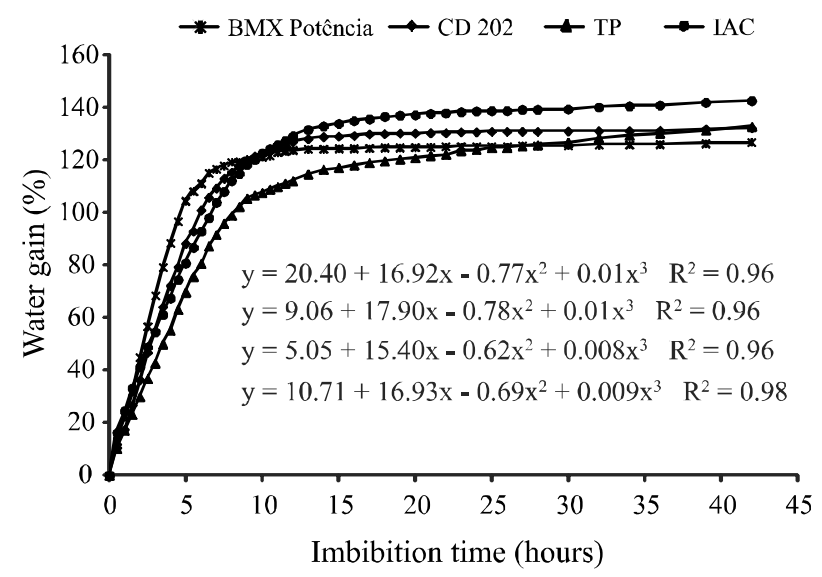


According to Marwanto (2004), genotypes that absorb water more slowly present higher germination values and lower electrical resistance. However, based on the germination and electrical conductivity results (Tables 2 and 4), this assertion does not apply to the present study.

In the case of genotypes with yellow coat, special attention should be given to the BMX Potência RR cultivar. This, generally, presented inferior results to the other genotypes evaluated in some tests performed, such as root length and total height after immersion of the seeds (Table 3). Despite not differing in similarity in some tests, the values for vigor in the CD 202 cultivar were lower in some cases. This can be related to the greater speed of hydration in the seeds of this genotype compared to the other varieties. This may hinder the appropriate reorganization of the cell membranes due to the stress caused by excess water reaching the inside of the seed in this initial phase of the germination process.

In relation to the radicle protrusion, for BMX Potência RR and CD 202, this structure was observed emerging after approximately 39 hours soaking. This result is in line with that observed by Carvalho et al. (2012), who found the radicle protrusion in soybean seeds with yellow coats emerged after 38 and 39 hours of soaking for the CD 206 RR and conventional CD206, respectively.

The radicle protrusion appeared precociously in the genotypes with black coats in relation to the former. The radicle protrusion occurred after 28 hours in the IAC and after 30 hours soaking in the TP. This response is important, since the increased speed in seed germination and seedling emergence in the field results in the reduced exposure of the seed to attack by pathogenic microorganisms.

Based on the confirmed results, the contributions contrasting genotypes have to offer the scientific community to improve the physiological quality of soybean seeds became evident. This is possible by means of genetic improvements, which makes use of biotechnological tools, taking advantage of the intrinsic characteristics of this type of genotype that can be of agronomic interest such as the increased resistance of the coat and the lower speed of the hydration process, contributing to improvement in the quality of seeds currently produced.

\section{CONCLUSIONS}

1. Genotypes with black coats, especially IAC, present greater physiological quality in relation to those with yellow coats;
2. The genotypes with yellow coats have a greater thousand weight seeds;

3. The BMX Potência RR genotype, with yellow coat, presents greater hydration than the other genotypes in the first hours of imbibitions and TP, with black coat, presents the least;

4. The radicle in black coats appears more rapidly than genotypes with yellow coats.

\section{ACKNOWLEDGEMENTS}

CNPq, FAPERGS and CAPES for the grant and other financial aid.

\section{REFERÊNCIAS}

ANDRADE, E. R. de. Caracterização e comparação da linhagem de soja UNB 1125 de tegumento preto com genótipos comerciais. 2012. 40 f. Monografia (Graduação em Agronomia) - Faculdade de Agronomia e Medicina Veterinária, Universidade Nacional de Brasília, Brasília, 2012.

BAHRY, C. A. et al. Chemical composition and structural characterization of contrasting colors of soybean seed coats. Semina: Ciências Agrárias, v. 36, n. 3, 2015. Suplemento 1.

BRACCINI, A. de L. et al. Condicionamento osmótico de sementes de soja. Revista Brasileira de Sementes, v. 19, n. 1, p. 71-79, 1997.

BRASIL. Ministério da Agricultura, Pecuária e Abastecimento. Regras para análise de sementes. 1. ed. Brasília, DF, 2009. 398 p.

CARRARO, I. M.; PESKE, S. T. Uso de sementes de soja no estado do Paraná. Revista Brasileira de Sementes, v. 27, n. 2, p. 75-80, 2005.

CARVAlho, T. C. de et al. Comparação da qualidade fisiológica de sementes de soja convencional e de sua derivada transgênica. Revista Brasileira de Sementes, v. 34, n. 1, p. 164-170, 2012.

FEHR, W. R.; CAVINESS, C. E. Stages of soybean development. Ames: Iowa State University of Science and Technology, 1977. 11 p. (Special Report, 80).

FLOR, E. P. O. et al. Avaliação de danos mecânicos em sementes de soja por meio de análise de imagens. Revista Brasileira de Sementes, v. 26, n. 1, p. 68-76, 2004.

GRIS, C. F. et al. Qualidade fisiológica e teor de lignina no tegumento de sementes de soja convencional e transgênica RR submetidas a diferentes épocas de colheita. Ciência Agrotécnica, v. 34, n. 2, p. 374-381, 2010.

INSTITUTO NACIONAL DE METEOROLOGIA. 2013. Disponível em: <http://www. inmet.gov.br>. Acesso em: 20 set. 2015 . 
MA, E. et al. Cracks in the palisade cuticle of soybean seed coats correlate with their permeability to water. Annals of Botany, v. 94, n. 2, p. 213-228, 2004.

MAGUIRE, J. D. Speed of germination - aid in selection and evaluation for seedling emergence and vigor. Crop Science, v. 2, n. 2, p. 176-177, 1962.

MARWANTO. Soybean seed coat characteristics and its quality losses during incubator aging and storage. Jurnal Ilmu-Ilmu Pertanian Indonesia, v. 6, n. 2, p. 57-65, 2004.

MENEZES, M. de et al. Aspectos químicos e estruturais da qualidade fisiológica de sementes de soja. Pesquisa Agropecuária Brasileira, v. 44, n. 12, p. 1716-1723, 2009.

MERTZ, L. M. et al. Diferenças estruturais entre tegumentos de sementes de soja com permeabilidade contrastante. Revista Brasileira de Sementes, v. 31, n. 1, p. 23-29, 2009.

MOÏSE, J. A. et al. Seed coats: structure, development, composition, and biotechnology. In Vitro Cellular \& Developmental Biology - Plant, v. 41, n. 5, p. 620-644, 2005.

PESKE, S. T.; BAUDET LABBÉ, L. M. Beneficiamento de sementes. In: PESKE, S. T.; VILLELA, F. A.; MENEGHELLO, G. E. Sementes: fundamentos científicos e tecnológicos. 3. ed. Pelotas: UFPel, 2012. cap. 6, p. 373-426.

PESKE, S. T.; PEREIRA, L. A. G. Tegumento da semente de soja. Tecnologia de Sementes, v. 6, n. 1/2, p. 23-34, 1983.

RANATHUNGE, K. et al. Properties of the soybean seed coat cuticle change during development. Planta, v. 231, n. 5, p. 11711188,2010
SANTOS, E. L. dos et al. Qualidade fisiológica e composição química das sementes de soja com variação na cor do tegumento. Revista Brasileira de Sementes, v. 29, n. 1, p. 20-26, 2007.

SHAO, S. et al. The outermost cuticle of soybean seeds: chemical composition and function during imbibition. Journal of Experimental Botany, v. 58, n. 5, p. 1071-1082, 2007.

SOUZA, F. H. D. de; MARCOS-FILHO, J. The seed coat as a modulator of seed - environment relationships in Fabaceae. Brazilian Journal of Botany, v. 24, n. 4, p. 365-375, 2001.

TAVARES, D. Q. et al. Características estruturais do tegumento de sementes permeáveis e impermeáveis de linhagens de soja. Brazilian Journal of Botany, v. 10, n. 2, p. 147-153, 1987.

TILlMANN, M. A. A.; MENEZES, N. L. de. Análise de sementes. In: PESKE, S. T.; VILLELA, F. A.; MENEGHELLO, G. E. Sementes: fundamentos científicos e tecnológicos. 3. ed. 2012. cap. 3, p. 161-272.

VANZOLINI, S. et al. Teste de comprimento de plântula na avaliação da qualidade fisiológica de sementes de soja. Revista Brasileira de Sementes, v. 29, n. 2, p. 90-96, 2007.

WEBER, H.; BORISJUK, L.; WOBUS, U. Molecular physiology of legume seed development. Annual Review of Plant Biology, v. 56, n. 1, p. 253-279, 2005.

ZIMMER, P. D. Fundamentos da qualidade da semente. In: PESKE, S. T.; VILLELA, F. A.; MENEGHELlO, G. E. (Org.). Sementes: fundamentos científicos e tecnológicos. 3. ed. Pelotas: UFPel, 2012. p.105-160. 